\title{
Compression directions in southern California (from Santa Barbara to Los Angeles Basin) obtained from borehole breakouts
}

\author{
Melita Wilde and Joann Stock \\ Seismological Laboratory, California Institute of Technology, Pasadena
}

\begin{abstract}
Borehole elongation in 71 drill holes was used to infer breakout orientation and directions of maximum horizontal principal stress $S_{\mathrm{H}}$ for six areas west of the San Andreas fault in southern California: Santa Barbara, Ojai, Central Ventura Basin, East Ventura Basin, West Los Angeles Basin, and East Los Angeles Basin. Breakouts were determined from analysis of oriented four-arm caliper data. The breakouts form at the position of the maximum compressive stress on the borehole wall; if the borehole is vertical and parallel to one of the principal stress directions, the breakouts will form parallel to the minimum horizontal principal stress $S_{\mathrm{h}}$, orthogonal to the maximum horizontal principal stress $S_{\mathrm{H}}$. Observations from deviated boreholes permit some constraints on the relative magnitudes of the principal stresses. In most cases the data permit either a thrust faulting $\left(S_{\mathrm{V}}<S_{\mathrm{h}}<S_{\mathrm{H}}\right)$ or strike-slip faulting $\left(S_{\mathrm{h}}<S_{\mathrm{V}}<S_{\mathrm{H}}\right)$ stress regime with NE to NW directions of $S_{\mathrm{H}}$. These results are broadly consistent with results from focal mechanism studies [Hauksson, 1990; $L i, 1996$ ] and with breakout and focal mechanism data present in the world stress map database [Zoback, 1992]. However, we find systematic variations in $S_{\mathrm{H}}$ directions suggestive of strong heterogeneity in the stress field at shallow depths, similar to that present in the Cajon Pass borehole [Shamir and Zoback, 1992]. Anomalous NW directions of $S_{\mathrm{H}}$ in the San Fernando Valley region and near the Whittier fault may be related to structural complexities and/or lateral ramps in nearby fault systems.
\end{abstract}

\section{Introduction and Discussion of Technique}

A knowledge of the stress regime in southern California, and how it may vary in space and time, is important to our understanding of the overall tectonic regime and to the seismic cycle on major fault systems (Figure 1). Recent work has focused on attempting to calculate how displacement on a single fault may locally change the stress field, and load or unload fault systems, bringing them closer to, or farther from, failure [e.g., Jaumé and Sykes, 1992; Harris and Simpson, 1992; Stein et al., 1994]. However, such calculations would benefit from a knowledge of the complete stress tensor in order to evaluate when a fault may be near failure. Currently, the complete stress tensor as a function of positions and time is one of the least well understood aspects of southern California tectonics.

As part of ongoing efforts to improve our knowledge of the stress regime in southern California, we have been reviewing all available data from old well logs which may contain information pertinent to the stress field. In particular, we are studying borehole breakouts, which are often recorded on oriented four-arm caliper data, a commonly collected type of well log data since development of the four-arm dipmeter tool in the mid-1960s. Many logs of this type are on file in archives of the California Division of Oil and Gas.

In this study we evaluate data from both vertical boreholes and nonvertical (deviated) boreholes. Most previous studies have only looked at breakouts in vertical holes, which limits one's knowledge to only the direction of the horizontal maximum and minimum principal stresses. Even calculations based on data from vertical drill holes might be misleading, since they rely upon the assumption that one of the principal stress directions is vertical. Under certain circumstances, data from

Copyright 1997 by the American Geophysical Union.

Paper number 96JB03734.

0148-0227/97/96JB-03734\$09.00 deviated boreholes may provide further information on the stress tensor, including constraints on the relative magnitudes of the principal stresses and identification of cases in which the principal stress directions are neither vertical nor horizontal [Peska and Zoback, 1995; Zajac and Stock, 1997].

The interpretation of stress directions from breakouts has been discussed by numerous authors (see summaries by Plumb and Hickman [1985] and Mastin [1988]) and will only be briefly reviewed here. Breakouts, or well bore spalling, form at the position of greatest hoop stress at the borehole wall. If the borehole is vertical and the far-field principal stresses are horizontal and vertical, then the breakout forms at the azimuth of the minimum horizontal principal stress $\left(S_{\mathrm{h}}\right)$. Tensile fractures such as hydraulic fractures would form at a borehole position orthogonal to the breakouts, in an orientation perpendicular to the least horizontal principal stress. For a situation with vertical drill holes, and vertical and horizontal principal stress directions, it is thus straightforward to infer the direction of $S_{\mathrm{h}}$ from the breakout azimuth, with the azimuth of $S_{\mathrm{H}} 90^{\circ}$ away from it. This technique has been used to establish global directions of $S_{\mathrm{H}}$ and $S_{\mathrm{h}}$, in conjunction with other data relevant to the stress field, including earthquake focal mechanisms, hydraulic fracturing stress measurements in boreholes, overcoming, and slip directions of young faults [e.g., Zoback, 1992]. The use of borehole breakouts alone does not constrain the type of stress regime (thrust, strike-slip, or normal) because the breakouts in vertical holes do not constrain the magnitude of the vertical stress $S_{\mathrm{v}}$ relative to the two horizontal principal stresses.

If the borehole is not vertical, or if none of the principal stress directions is vertical, the orientation of breakouts is not as simply related to the principal stress directions. However, more constraints on the stress field can potentially be obtained. If enough boreholes of varying orientations are available in a small region, the breakout orientations in these holes may constrain the complete stress tensor, including the relative 


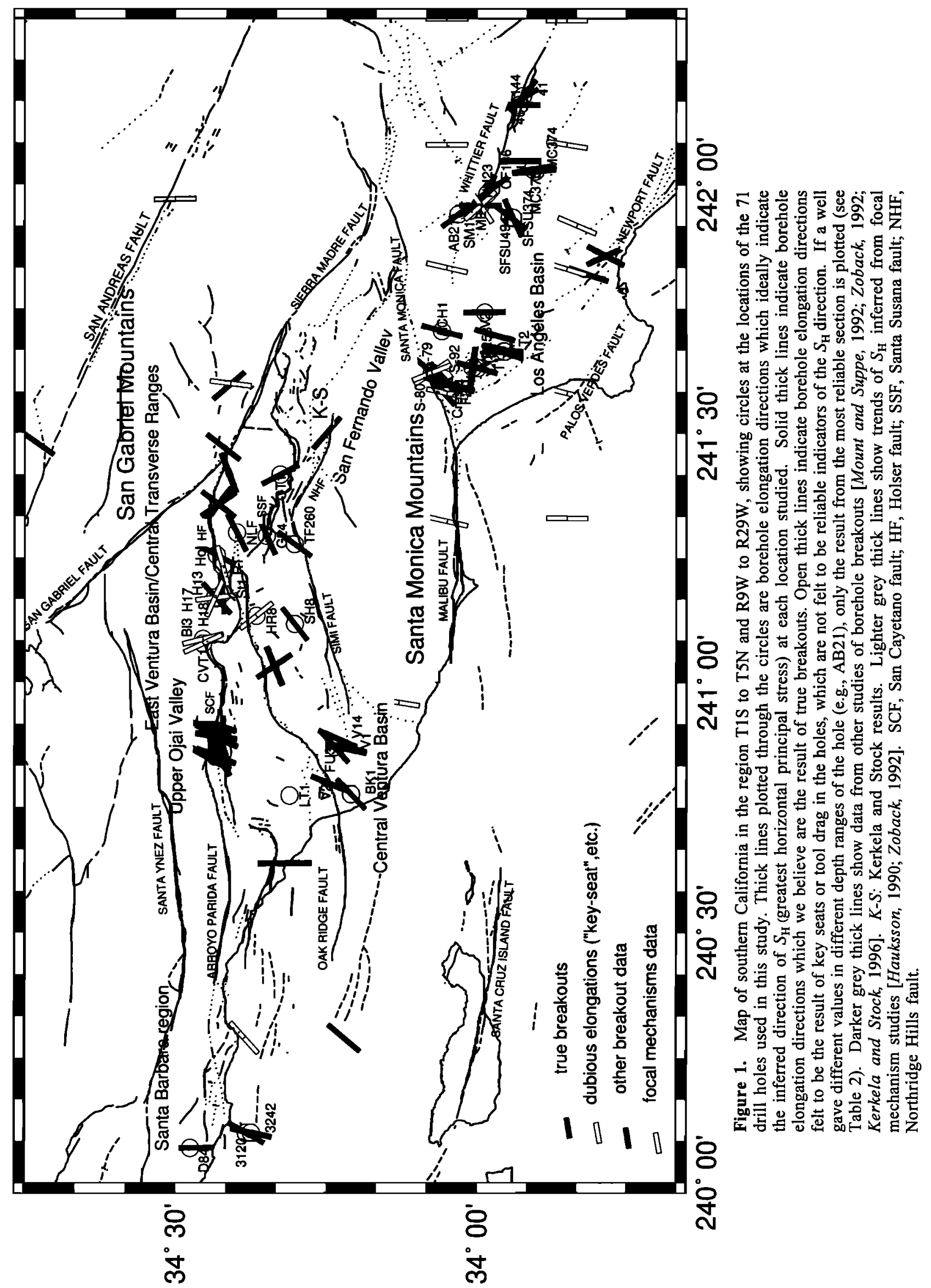


magnitudes of the principal stresses. The details of this technique were first suggested by Mastin [1988] and have been recently summarized by Qian and Pedersen [1991] and Zajac and Stock (1997).

\section{Calculating the Breakout Azimuth From Dipmeter Data}

There are two aspects of deriving breakout orientations from oriented dipmeter data in a noncylindrical well bore: determining the direction of well bore elongation, and evaluating whether this well bore elongation is caused by the presence of a breakout or by something else. Dipmeter tools determine orientations using a three-axis magnetometer and thus determine orientations reliably regardless of the borehole deviation. Data needed to calculate the borehole elongation as a function of depth in a well include (1) oriented four-arm caliper data, (2) borehole azimuth, and (3) borehole deviation.

Before assuming that the azimuth of borehole elongation represents a breakout, the quality of the dipmeter data must be carefully examined. Only if the dipmeter data meet our specifications will a breakout azimuth be calculated. The data must satisfy a series of criteria (modified after Plumb and Hickman [1985]) to eliminate elongations due to washouts, pinch-ins of the hole, and tool malfunction (Zajac and Stock, 1997): (1) The tool rotation stops in the zone of elongation. (2) The caliper arm difference is greater than 0.5 inches $(1.3 \mathrm{~cm})$. (3) The smaller of the caliper readings is close to bit size (within $5 \%$ of bit size). (4) The length of the elongation zone is greater than 10 feet $(3.05 \mathrm{~m})$. (5) The directions of elongation should not consistently coincide with the azimuth of the high and low sides of the borehole when the hole deviates from vertical.

The first criterion locates sections of the well where the tool was prevented from rotating, presumably due to the friction of contact with the wall of the borehole in the zone of elongation. The second criterion utilizes the fact that the breakout must exceed a certain size in order to halt tool rotation. The third criterion excludes data recorded in sections of well where the tool was off center or the hole was washed out. The fourth criterion accounts for the inability of the tool to detect breakouts smaller than the pad length. The fifth criterion eliminates data where the tool may have scraped along the low side of an inclined borehole, digging its own elliptical channel (a "key seat"). We applied this criterion on a case-by-case basis, as discussed below, because in thrust faulting and some strikeslip faulting stress regimes, breakouts would be expected to form on the high and low sides of the hole, particularly at higher borehole deviations. In some other studies [e.g., Qian and Pedersen, 1991], breakouts in these orientations have been retained and used to constrain the stress state.

Calculation of the breakout direction for a four-arm dipmeter is relatively straightforward. Plumb and Hickman [1985] showed that the larger caliper diameter generally tracks the axis of the breakout (the borehole elongation direction). Breakouts are assumed to form symmetrically in the borehole, so their directions are defined between $0^{\circ}$ and $180^{\circ}$ azimuth (Zajac and Stock, 1997). They form at the position of maximum hoop stress on the borehole wall. This position is a function of the complete stress tensor affecting the region of the borehole and of the borehole orientation. In the most general case, both the borehole and the principal stress directions lie at arbitrary angles with respect to the vertical. In this situation, as the borehole orientation changes in a constant stress field, the position of maximum hoop stress on the borehole wall varies, and hence the expected breakout orientation also varies. A sufficient number of observations would allow one to invert for the complete stress tensor in the region (Zajac and Stock, 1997). In a more common case, if the borehole is near vertical and if the principal stresses are horizontal and vertical, then one can recover the direction of maximum horizontal principal stress $\left(S_{\mathrm{H}}\right)$ since this is perpendicular to the direction of elongation of the borehole breakouts. The direction of least horizontal principal stress, $S_{\mathrm{h}}$, will be orthogonal to this. Note that in this case, information on stress magnitudes cannot be recovered unless other assumptions are made [e.g., Moos and Zoback, 1990; Vernik and Zoback, 1992].

\section{Representation of Data and Results}

In order to evaluate the possibilities of determining the complete stress tensor from our data, we plot the breakout orientations on a lower hemisphere stereographic projection and then we compare them to theoretical breakout patterns for various stress states (Figures 2 and 3 ). Data from vertical boreholes would be plotted at the center of each circular plot, and data from more horizontal holes would plot at the periphery. Nonvertical holes are shown as a function of their inclination with respect to vertical (radial distance from the center) and trend (azimuth measured clockwise from north). Each tick mark on this plot represents an inferred breakout orientation. Solid circles on the theoretical plots represent points where the stress anisotropy is zero [Peska and Zoback, 1995; Zajac and Stock, 1997]; at these borehole orientations, breakouts might be absent, or they will change orientation rapidly as borehole

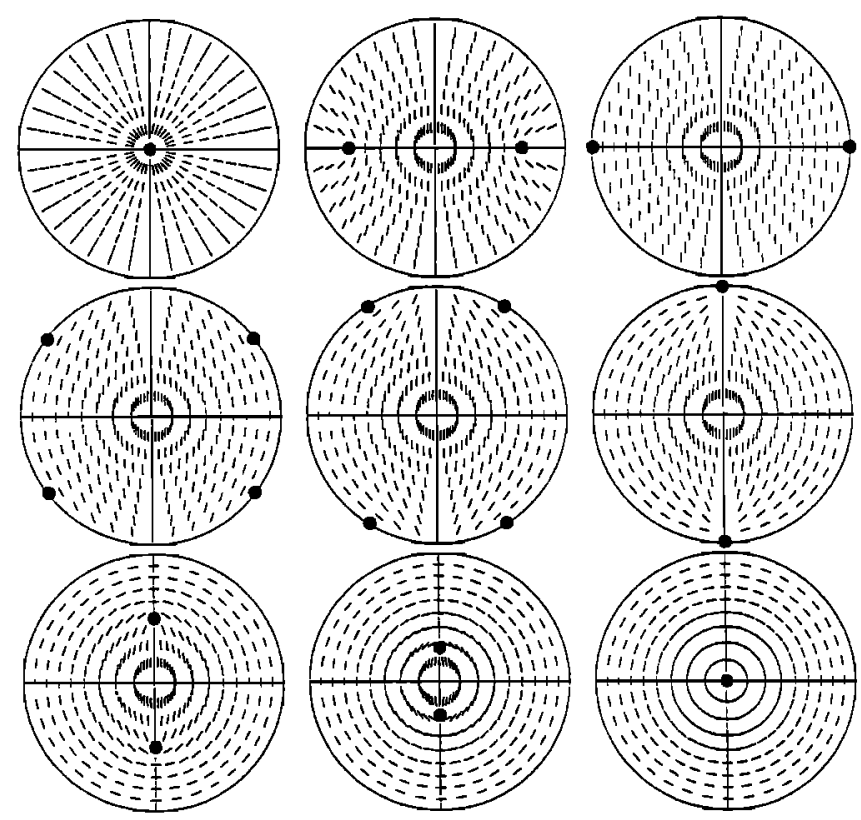

Figure 2. Lower hemisphere stereographic projections showing theoretical patterns of borehole breakouts, projected onto the horizontal plane, for a variety of borehole orientations and stress regimes (see Zajac and Stock, 1997). The top left plot shows a pure degenerate thrust stress faulting stress regime. The top middle and top right plots show a combination of thrust and strike-slip faulting where $\phi=0.5$, and $\phi=0$. The middle row of plots shows two strike-slip stress regimes on the left, $\phi=0.5$, and the middle $\phi=0.8$, to a combination of normal and strike-slip regimes on the right where $\phi=1$. The bottom row shows various cases of a normal stress regime where $\phi=0.5$ on the left and $\phi=0.2$ in the middle, ending at a degenerate normal stress regime on the right where $\phi=0$. Large dots are points where the stress anisotropy is zero, corresponding to borehole orientations with no preferred breakout direction. The low maximum compressive stress at the borehole wall at these positions indicates that breakouts might be absent. If breakouts are present near the nodal points, however, they will change orientation rapidly as borehole orientations vary. 


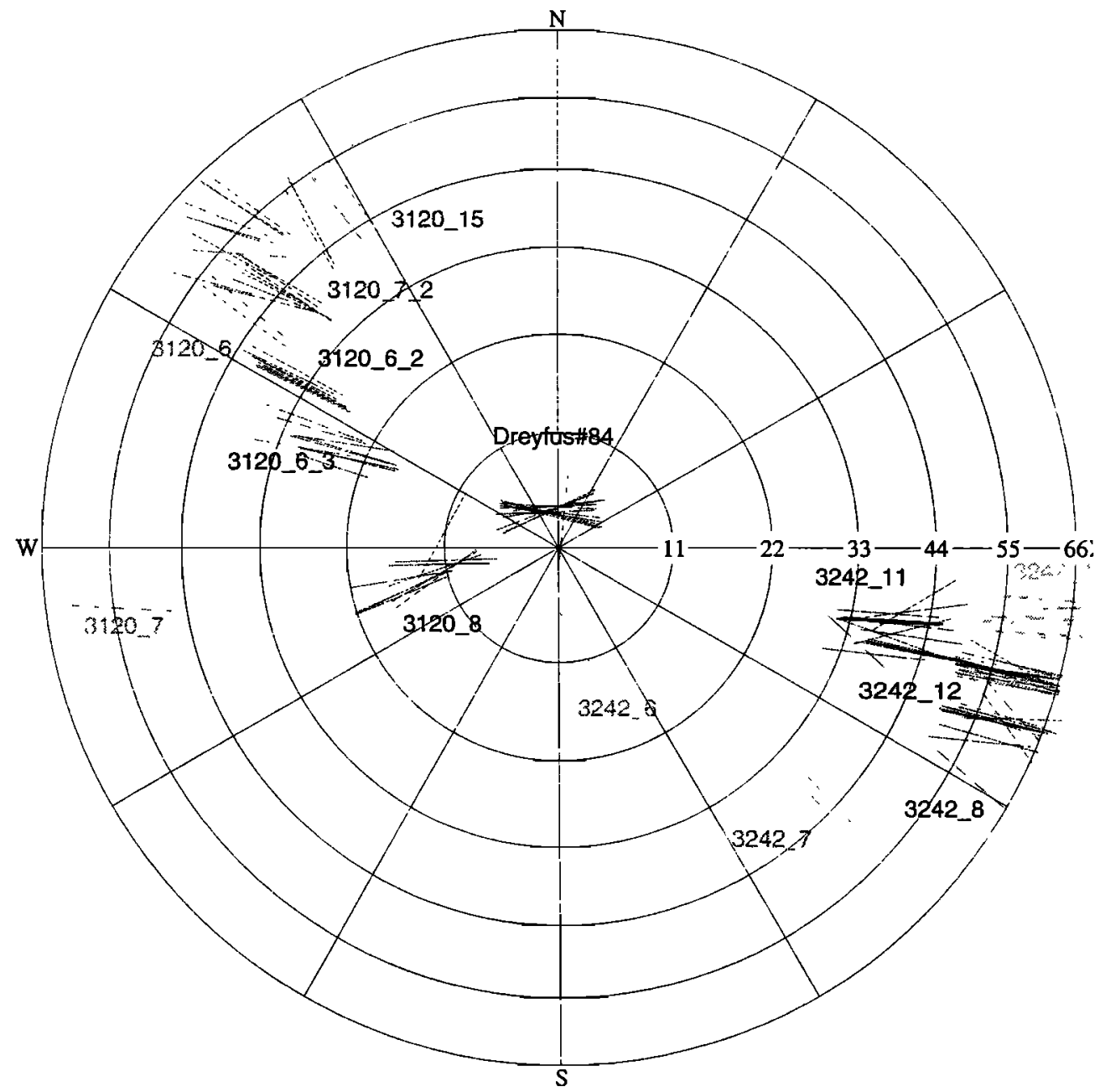

Figure 3a. Lower hemisphere stereographic projection of borehole elongation directions from boreholes studied for the Santa Barbara region. Plotting conventions: analyzed breakout directions are plotted as graduate shaded lines parallel to the breakout trend in map view, at the position corresponding to the appropriate borehole trend and plunge. Shading of breakout lines is used to distinguish data from different wells. There is a dominant ENE trend of breakout azimuths at low borehole deviations, suggesting a $N 13^{\circ} \mathrm{E} \pm 9^{\circ}(1 \sigma)$ direction of compression. The stress ratio, $\phi$, may be equal to about 0.5 .

orientations vary. Various authors have used this approach to present borehole breakout and stress tensor data. Mastin [1988] introduced the method as the most useful for illustrating the pattern of breakout directions; Zajac and Stock (1997) used same methodology to show patterns of breakout orientations that would be predicted for arbitrarily oriented drill holes subjected to certain characteristic stress fields. Peska and Zoback [1995] used this methodology to study inclined boreholes and plotted projections "looking down the hole" to ease the presentation and visualization of orientation of failures in holes of all orientations, even in nearly horizontal holes.

Figure 2 shows theoretical stereographic projections of breakout orientations, projected onto a horizontal plane, for a variety of borehole orientations in the thrust faulting, strikeslip faulting and normal faulting regimes, as well as combinations of stress regimes [after Mastin, 1988; Peska and Zoback, 1995; Zajac and Stock, 1997]. The characteristic stress fields are defined by the orientations of $S_{1}, S_{2}$, and $S_{3}$ and the stress ratio $\phi=\left(S_{2}-S_{3}\right) /\left(S_{1}-S_{3}\right)$, where $S_{1}$ is the maximum stress, $S_{2}$ is the intermediate stress, and $S_{3}$ is the minimum stress. If ana- lyzed breakout data show enough variation in borehole orientations, the stress state can be reascnably constrained, since the patterns vary continuously from radial breakout azimuths (for thrust faulting, $S_{\mathrm{H}}=S_{\mathrm{h}}>S_{\mathrm{v}}$ ) to a circumferential distribution of breakout azimuths (for normal faulting, $S_{\mathrm{V}}>S_{\mathrm{H}}=S_{\mathrm{h}}$ ).

Using these stereographic projections, the observations were compared to theoretical plots for different stress states. A rough estimate of the best fitting stress state was made by eye. As the borehole orientation changes, so does the breakout orientation, resulting in a unique breakout pattern for each stress state. For pure normal faulting and pure thrust faulting, the breakouts change azimuth most rapidly for near-vertical (low deviation) holes. However, in the strike-slip regime, breakout orientations are expected to be fairly constant for holes close to vertical and should only change rapidly at higher borehole deviations.

Caliper-derived borehole elongations aligned with the high and low sides of the hole (radial on a stereographic plot) usually have been considered unreliable indicators of the compressive stress direction. This is because they could represent tool drag (a "key seat") on the bottom of the hole, a common 


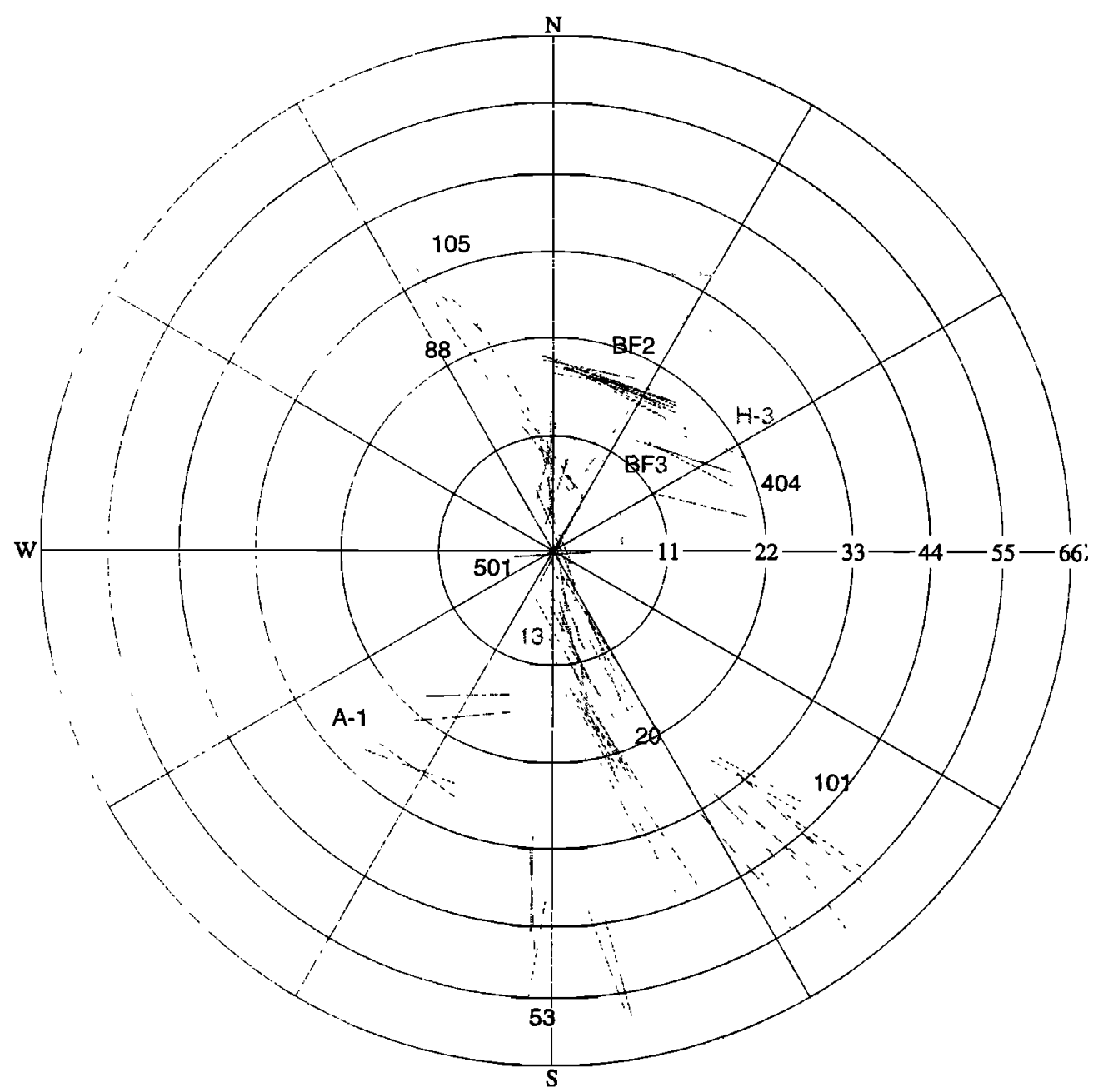

Figure 3b. Same as Figure 3a, except for Upper Ojai Valley. Breakouts considered most reliable for constraining the stress direction are those trending WNW. The stress ratio, $\phi$, is approximately 0.5 , and the direction of maximum horizontal compression $\left(S_{\mathrm{H}}\right)$ is $\mathrm{N} 20^{\circ} \mathrm{E} \pm 4^{\circ}$.

problem in boreholes that are highly deviated. Key seats can be easily distinguished from breakouts on borehole televiewer logs, but the borehole televiewer is not a routinely used well logging device, and televiewer logs were not available in any of the wells we studied. Nevertheless, there are some borehole orientations for which the breakouts are expected to be radial [Mastin, 1988; Zajac and Stock, 1997]. Various authors have theoretically and experimentally investigated results of inclined boreholes and have found that highly deviated holes do not give reliable results [Daneshy, 1973; Richardson, 1981; Baumgartner, 1989]. However, in some cases, caliper-derived elongation data from highly deviated drill holes have been retained and used in stress field determinations [e.g., Qian and Pedersen, 1991]. Thus we do not disregard radial borehole elongations without more careful evaluation. In the discussions below we individually evaluate the extent of key seats likely to be present in the data.

\section{Data}

We studied data from 71 boreholes in the southern California area in the region $117^{\circ}-120^{\circ} \mathrm{W}, 33.5^{\circ}-34.5^{\circ} \mathrm{N}$ (T1S$5 \mathrm{~N}$; R9W-29W). In most cases, microfilm prints of the raw dipmeter logs were obtained from the California Department of Conservation, Division of Oil and Gas archives, and then digitized. Some digital data were also obtained from Mobil Oil
Company. Digitized values were analyzed for borehole elongation directions subject to the criteria described above, following Zajac and Stock (1997). A value of $15^{\circ} \mathrm{E}$ was used for the magnetic declination to correct the observations to geographic north. We give weighted average values of breakout orientations, with weights corresponding to the length of each breakout.

The wells were divided into six geographic regions (Tables 1 and 2): Santa Barbara area, Upper Ojai Valley, Central Ventura Basin, East Ventura Basin, West Los Angeles Basin, and East Los Angeles Basin, in order to separate data from possibly different stress regimes. Individual breakout orientations were plotted on lower hemisphere stereographic projections (Figure 3) and compared to corresponding theoretical plots (Figure 2) to evaluate the stress regime separately for each region. A sample well $\log$ showing the details of data, and the resultant locations of breakouts identified, is shown in Figure 4.

\section{Santa Barbara Region}

All of the wells except one (Dreyfus \#84) are highly deviated offshore wells from two platforms: 3120 and 3242 (see Figure 1 for locations). The depth range of the data varied from $275 \mathrm{~m}$ to $2927 \mathrm{~m}$ below sea level.

Dreyfus \#84 is a nearly vertical borehole whose results are 


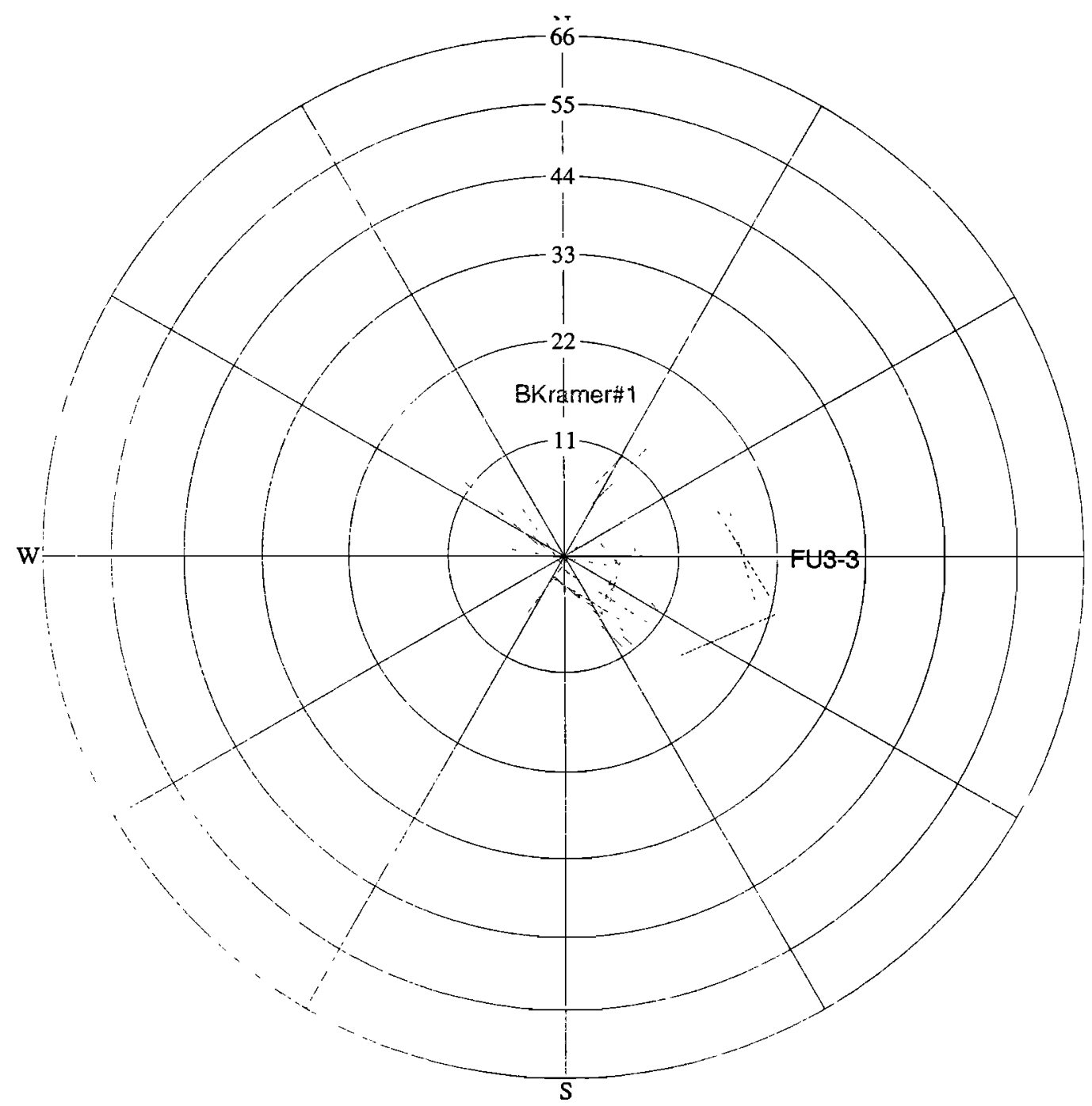

Figure 3c. Same as Figure 3a, except for Central Ventura Basin. The few breakouts present trend dominantly $\mathrm{NW}$ suggesting a compression direction of $\mathrm{N} 47^{\circ} \mathrm{E} \pm 22^{\circ}$.

very helpful to constrain the direction of the horizontal principal stress (Figures 3a and 4). This hole shows an E-W trend of the breakout azimuth, corresponding to an average direction of $\mathrm{N} 88^{\circ} \mathrm{W}$, which implies a maximum compressive stress direction of $\mathrm{N} 2^{\circ} \mathrm{E}$.

This result agrees with breakouts from inclined offshore boreholes from the platforms 3120 and 3242 . Most of the boreholes from platform 3120 plunge NW; boreholes from platform 3242 plunge toward the east quadrant. Borehole deviations at the locations of the observed borehole elongations are as high as $60^{\circ}$.

The lower hemisphere stereographic projection of these data (Figure 3a) best fits a theoretical stress state with NNE horizontal maximum compressive stress (Figure 2, top middle). A rough estimate of the best fitting stress state was made by eye. The $\phi$ value is not well constrained because many of the borehole elongations observed for higher borehole deviations are in the radial direction. Hence there is some doubt as to whether these can be considered true breakouts and included in the analysis.

\section{Upper Ojai Valley}

We analyzed data from 15 wells in the Ojai oil field, at approximately $34^{\circ} 25^{\prime} \mathrm{N} ; 119^{\circ} 6^{\prime} \mathrm{W}$ (Figure 5 ). These wells lie in region $\mathrm{T} 4 \mathrm{~N} ; \mathrm{R} 21 \mathrm{~W}-22 \mathrm{~W}$. The observation depths ranged from $+376 m$ to $-2307 m$ relative to sea level.

The data were plotted on a lower hemisphere stereographic projection, according to the conventions described above (Figure 3b). Borehole deviations ranged from $0^{\circ}$ to $50^{\circ}$. The non-radial elongation directions are dominated by NW trending azimuths, with an average breakout direction of $\mathrm{N} 70^{\circ} \mathrm{W}$. This result is dominated by the data from BF2, DN2, H3, A1, and 404 boreholes. These are the data which we trust the most. These data correspond to nonradial borehole elongation directions and/or low borehole deviations and are therefore likely to be more reliable. In map view (Figure 5) these holes show a generally consistent pattern of NNW trending $S_{\mathrm{H}}$ directions. We interpret these data to indicate a minimum compressive stress direction $S_{\mathrm{h}}$ of $\mathrm{N} 70^{\circ} \mathrm{W}$ and a maximum compressive stress direction $S_{\mathrm{H}}$ of $\mathrm{N} 20^{\circ} \mathrm{E}$. However, the data for near-vertical sections of boreholes are unusually scattered (Figure $3 \mathrm{~b}$ ) which may indicate local variations in the directions of the principal horizontal stresses. In general, these show a more EW to ENE-WSW direction of compression, compared to the NNE-WSW direction visible in the deeper data.

Other data, from BF3, 88, 101, 105, 13, and 53 boreholes, are dominantly radial; that is, they are along the high and low sides of the borehole and may result from key seats in the hole. 


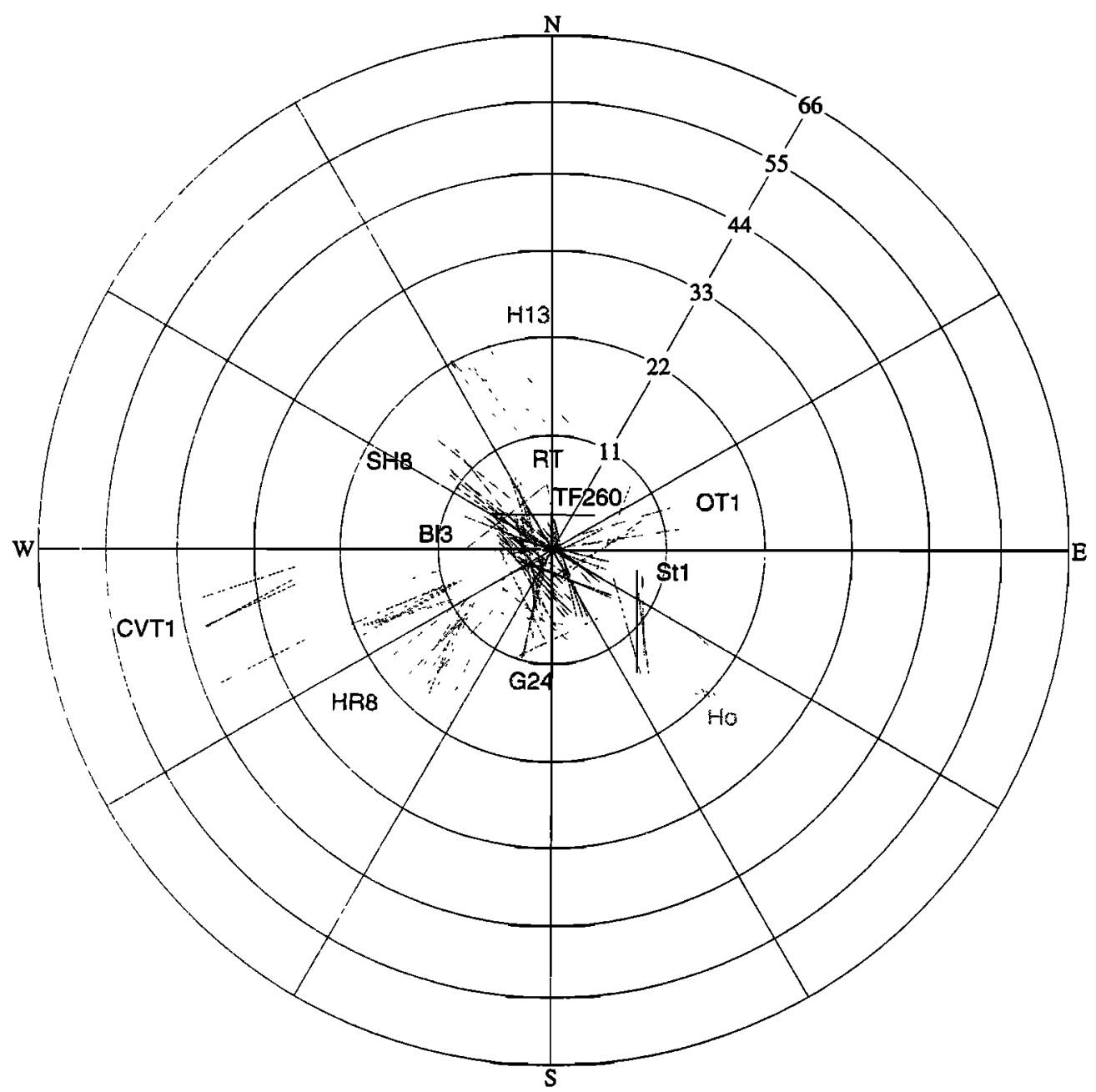

Figure 3d. Same as Figure 3a, except for East Ventura Basin/Central Transverse Ranges. Breakouts trend dominantly NW with a direction of maximum horizontal compression $\left(S_{\mathrm{H}}\right)$ of $\mathrm{N} 46^{\circ} \mathrm{E} \pm 16^{\circ}$.

As can be seen from Figure 5, these data show more scatter. We feel that they must be treated more carefully before being included in any analysis. Because radial breakouts are theoretically expected in a thrust faulting stress regime (Figure 2, top middle), it is possible that these are true breakouts. If so, the pattern of breakout orientations would suggest a thrust faulting stress regime with a value of $\phi$ of 0.5 (Figure 2, top middle). If we discount the radial elongation directions, the stress regime could be a combination of thrust and strike-slip faulting (Figure 2, top right), and the $\phi$ value is very poorly constrained. In any case, the directions of breakouts in these holes do not directly represent the directions of $S_{\mathbf{h}}$.

The Upper Ojai Valley is a tectonic depression between opposing reverse faults. Its northern border is formed by the active north dipping San Cayetano fault. This fault dies out farther west in Ojai Valley, where its displacement is transferred to a blind thrust [Huftile, 1991]. The southern border of the Upper Ojai Valley is formed by the Lion fault set which dips south. To the east, the San Cayetano fault overrides and folds the Lion fault set near the surface.

We have compared our results to data from Huftile [1991], who suggests a thrust faulting stress regime, in very good agreement with our results.

\section{Central Ventura Basin}

The next area examined was the Central Ventura Basin, south of the Ojai area (Figure 1). Only three wells could be analyzed because most of the archived logs available from this area were not of sufficient quality to be interpreted with any degree of confidence. The three wells are located in the Central Ventura Basin, between the south dipping Oak Ridge thrust fault and the north dipping Simi thrust fault. The depth ranges analyzed varied from 1220 to $4130 \mathrm{~m}$ below sea level.

The results (Figure $3 \mathrm{c}$ and Table 1) show a mixture of radial and nonradial borehole elongation directions. Borehole deviations were all less than $20^{\circ}$, low enough that key seats and tool drag should not be much of a problem. Thus, for this area, radial directions of elongation were included in the analysis.

Well Friedrich Unit 3-3 shows an average azimuth of elongation (interpreted to be breakout azimuth) of $\mathrm{N} 42^{\circ} \mathrm{W}$. This implies a maximum compressive stress direction $S_{\mathrm{H}}$ of $\mathrm{N} 48^{\circ} \mathrm{E}$. Well Ballard Kramer 1 shows NW trending breakout azimuths, with an average direction of $\mathrm{N}^{\circ} 3^{\circ} \mathrm{W}$. This implies a maximum compressive stress direction $S_{\mathrm{H}}$ of $\mathrm{N} 47^{\circ} \mathrm{E}$. The third well, Lloyd Tiger 1 , did not show any breakouts. The two wells with breakouts are in fairly good agreement. In combination, these data show an average trend of $N 43^{\circ} \mathrm{W}$ for the breakout azimuth. This implies a maximum compressive stress direction $S_{H}$ of $N 47^{\circ} \mathrm{E}$. Because of the low values of borehole deviations in these wells, no constraints could be placed on the value of $\phi$ in this area (Figure 2, top middle).

We compared these results with data from Mount and Suppe [1992]. Their wells V1, V2, and V14 show NW trending breakout azimuths at $N 77^{\circ} \mathrm{W}, \mathrm{N} 68^{\circ} \mathrm{W}$, and $N 66^{\circ} \mathrm{W}$, respec- 


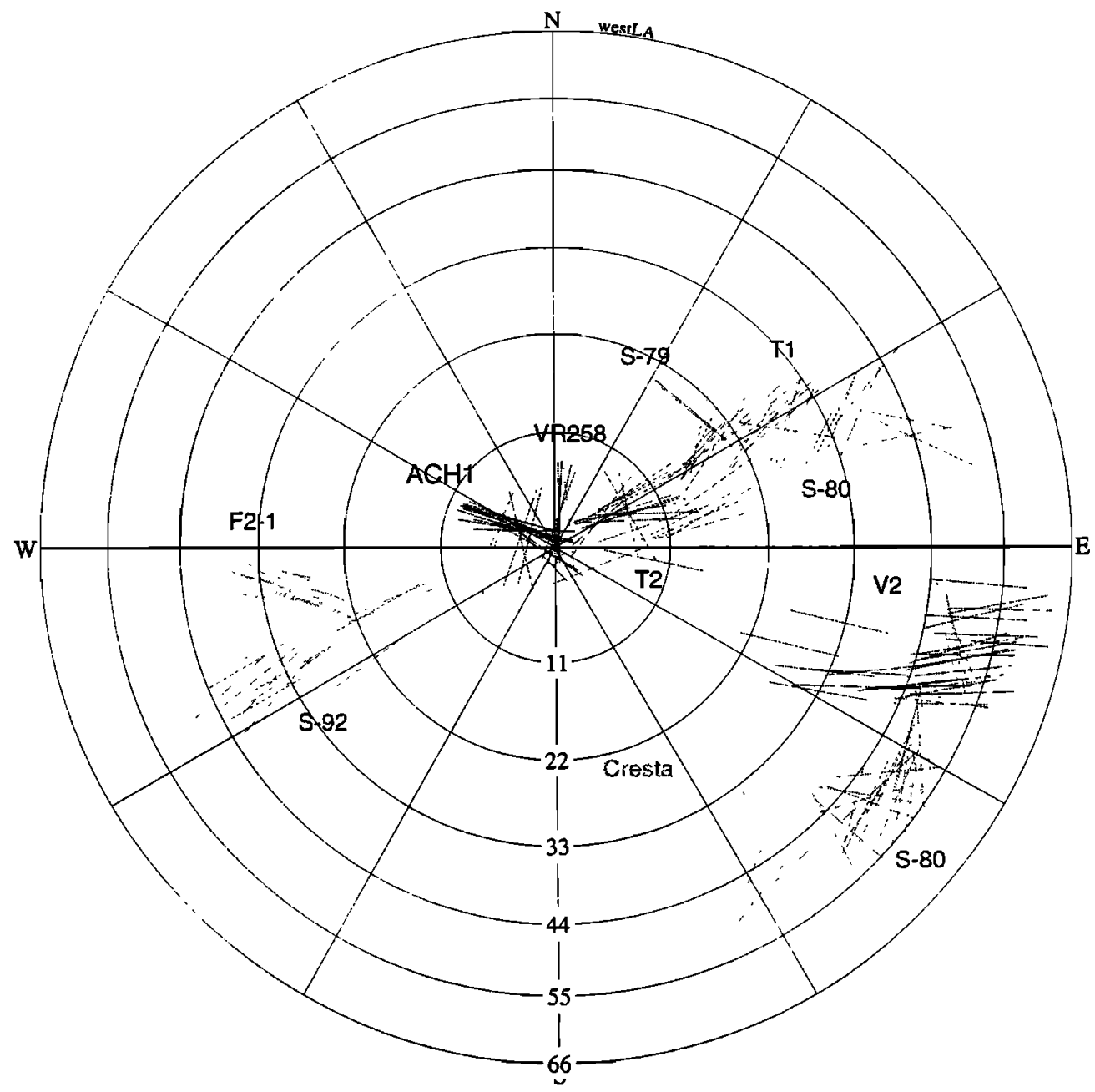

Figure 3e. Same as Figure 3a, except for West Los Angeles Basin. Dominant E-W strike of the breakout azimuths gives a direction of maximum horizontal compression $\left(S_{\mathrm{H}}\right)$ of $\mathrm{N} 0^{\circ} \mathrm{E} \pm 14^{\circ}$.

tively (Figure 1). These results are in reasonably good correspondence with our results, although they are about $20^{\circ}$ counterclockwise of our results and would thus suggest a more northerly (NNE) orientation of maximum compressive stress direction $S_{\mathrm{H}}$

\section{East Ventura Basin/Central Transverse Ranges}

We analyzed 14 wells in the East Ventura Basin/Central Transverse Ranges at approximately $34^{\circ} 18^{\prime} \mathrm{N}-28^{\prime} \mathrm{N}$ and $118^{\circ} 35^{\prime} \mathrm{W}-55^{\prime} \mathrm{W}$ (Figure 1). These wells lie in the region T3N$4 \mathrm{~N}$ and R17W-19W, east of the Ojai and Central Ventura Basin areas discussed above. Borehole deviations ranged from $0^{\circ}$ to $36^{\circ}$ and depths ranged from $+165 \mathrm{~m}$ to $-2866 \mathrm{~m}$, relative to sea level.

The borehole elongation directions show a mixture of orientations at low borehole deviations, with predominantly radial directions of borehole elongation at borehole deviations exceeding about $15^{\circ}$ (Figure 3d). Consequently, only the data from the less deviated holes (SH8, TF260, G24, NLF, RT, Hol, St1, and H13 boreholes) were used in the analysis. These observations are dominated by holes G24, RT, and TF260, which have NW trending breakout azimuths with an average direction of $\mathrm{N} 44^{\circ} \mathrm{W}$, implying a minimum compressive stress direction $S_{\mathrm{h}}$ of $\mathrm{N} 44^{\circ} \mathrm{W}$ and a maximum compressive stress direction $S_{\mathrm{H}}$ of $\mathrm{N} 46^{\circ} \mathrm{E}$.
We obtained very interesting results for Orcutt Trust 1 borehole, the easternmost well analyzed in this region. The OT1 borehole shows NE trending breakout azimuths, with an average direction of $\mathrm{N} 62^{\circ} \mathrm{E}$. So, $S_{\mathrm{h}}$ is $\mathrm{N} 62^{\circ} \mathrm{E}$, and $S_{\mathrm{H}}$ is $\mathrm{N} 28^{\circ} \mathrm{W}$ (Figure 1). This well may be under a different stress regime than the other wells we had analyzed in this region. Kerkela and Stock [1996] analyzed breakouts in near-vertical wells near the San Fernando Valley and found that the direction of $S_{\mathrm{H}}$ is $\mathrm{N} 49^{\circ} \mathrm{W}$. This is counterclockwise of the direction we see in the OT1 borehole, but nevertheless, both data show a NE breakout azimuth direction and a NW orientation of the maximum horizontal principal stress. Kerkela and Stock [1996] attributed the NW direction of compression to the structural transition between the Santa Susana fault system and the San Fernando fault system, where a lateral ramp occurs. The OT1 borehole lies west of the lateral ramp and therefore its breakout orientations suggest that $\mathrm{NW}$ directed compression may be a more regional feature in this area.

Elongations from wells CVT1 and HR8 are dominantly radial and may be the result of key seats or may indicate a different state of stress from that present in the other holes. Since CVT1 and HR8 are deviated $>15^{\circ}$, they are not included in the calculation of the $S_{\mathrm{H}}$ direction. However, hole CVT1 was very close to B13, which was nearly vertical and also showed breakout directions at odds with the NE compression seen in this area. B13 had two breakout zones which suggest a NNW 


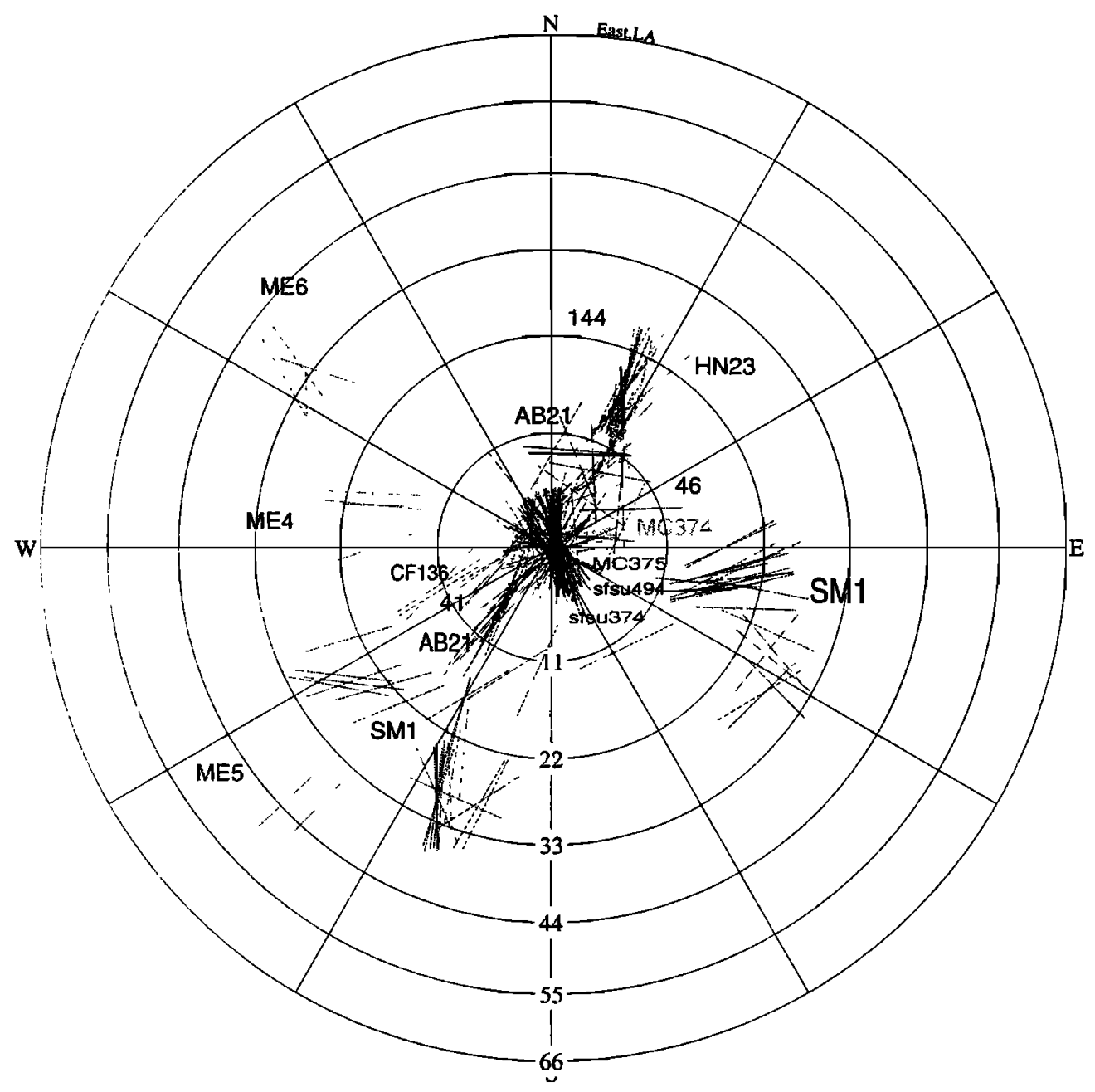

Figure 3f. Same as Figure 3a, except for East Los Angeles Basin. Breakout azimuths are highly variable but taken together they yield an $S_{\mathrm{H}}$ direction of $\mathrm{N} 59^{\circ} \mathrm{W} \pm 23^{\circ}$. Probably, there are large variations in the stress directions at shallow depths in this region.

trending $\left(\sim \mathrm{N} 15^{\circ} \mathrm{W}\right)$ azimuth of $S_{\mathrm{H}}$. We note that this is consistent with the orientations of elongations from the nearby hole CVT1. Thus the data from CVT1 may represent true breakouts rather than key seats and may indicate another zone of stress rotations at shallow depths along a reentrant in a thrust fault, this time along the San Cayetano fault (Figure 1). More data from other drill holes would be required to confirm this hypothesis.

The observations of the other low-deviation holes (except for OT1 and B13) (Figure 3d) would reasonably fit a theoretical plot for a thrust faulting stress regime with a maximum horizontal principal stress direction of NE-SW (Figure 2, top middle). This is roughly consistent with the tectonic setting of the East Ventura Basin. This is an active area with north dipping thrust faults, the San Cayetano, Santa Susana, San Fernando, and Simi faults, and with south dipping thrust faults, the Oak Ridge fault and the Holser Fault [Huftile, 1991].

\section{Los Angeles Basin}

The southwesternmost area of our analysis comprises the Los Angeles Basin at approximately $33^{\circ} 54^{\prime} \mathrm{N}-34^{\circ} 4^{\prime} \mathrm{N}$, $117^{\circ} 48^{\prime} \mathrm{W}-118^{\circ} 23^{\prime} \mathrm{W}$. We analyzed 25 wells in the region T3S-1S, R9W-14W. Deviations of the wells ranged up to $64^{\circ}$ from vertical. The depth range analyzed was from $+16 \mathrm{~m}$ to $-5076 \mathrm{~m}$ relative to sea level (Figures $3 \mathrm{e}$ and $3 \mathrm{f}$ ).
West Los Angeles Basin. Of the 11 boreholes analyzed in this area, four have breakouts in sections of hole with $<11^{\circ}$ deviation: ACH1, VR258, T1, and T2. These showed breakout orientations that were relatively consistent for a given well but different among the various wells (Table 2): ACH1 had breakout directions of $106^{\circ}$, implying that $S_{\mathrm{H}}$ is oriented $\mathrm{N} 16^{\circ} \mathrm{E}$; VR258 had breakouts oriented along $\mathrm{N8}{ }^{\circ} \mathrm{E}$, suggesting that $S_{\mathrm{H}}$ there is oriented $\mathrm{N} 82^{\circ} \mathrm{W}$; and $\mathrm{T} 1$ and $\mathrm{T} 2$ had intermediate orientations (with $S_{\mathrm{H}}$ values $\mathrm{N} 41^{\circ} \mathrm{W}$ and $\mathrm{N} 9^{\circ} \mathrm{W}$, respectively). The deeper breakouts from near-vertical holes, in

Table 1. Average Directions of Maximum Horizontal Principal Stress $S_{\mathrm{H}}$ Determined From Breakout Orientations in Subregions of the Study Area

\begin{tabular}{ll}
\hline \multicolumn{1}{c}{ Region } & Average $S_{\mathrm{H}}$ Direction \\
\hline Santa Barbara region & $\mathrm{N} 13^{\circ} \mathrm{E} \pm 9^{\circ}(1 \sigma)$ \\
Upper Ojai Valley & $\mathrm{N} 20^{\circ} \mathrm{E} \pm 4^{\circ}$ \\
Central Ventura Basin & $\mathrm{N} 47^{\circ} \mathrm{E}+22^{\circ}$ \\
East Ventura Basin/Central Transverse Ranges & $\mathrm{N} 46^{\circ} \mathrm{E} \pm 16^{\circ}$ \\
West Los Angeles Basin & $\mathrm{N} 0^{\circ} \mathrm{E} \pm 14^{\circ}$ \\
East Los Angeles Basin & $\mathrm{N} 59^{\circ} \mathrm{W} \pm 23^{\circ}$
\end{tabular}

The standard deviation of the result for each subregion is given by $\sigma$. 


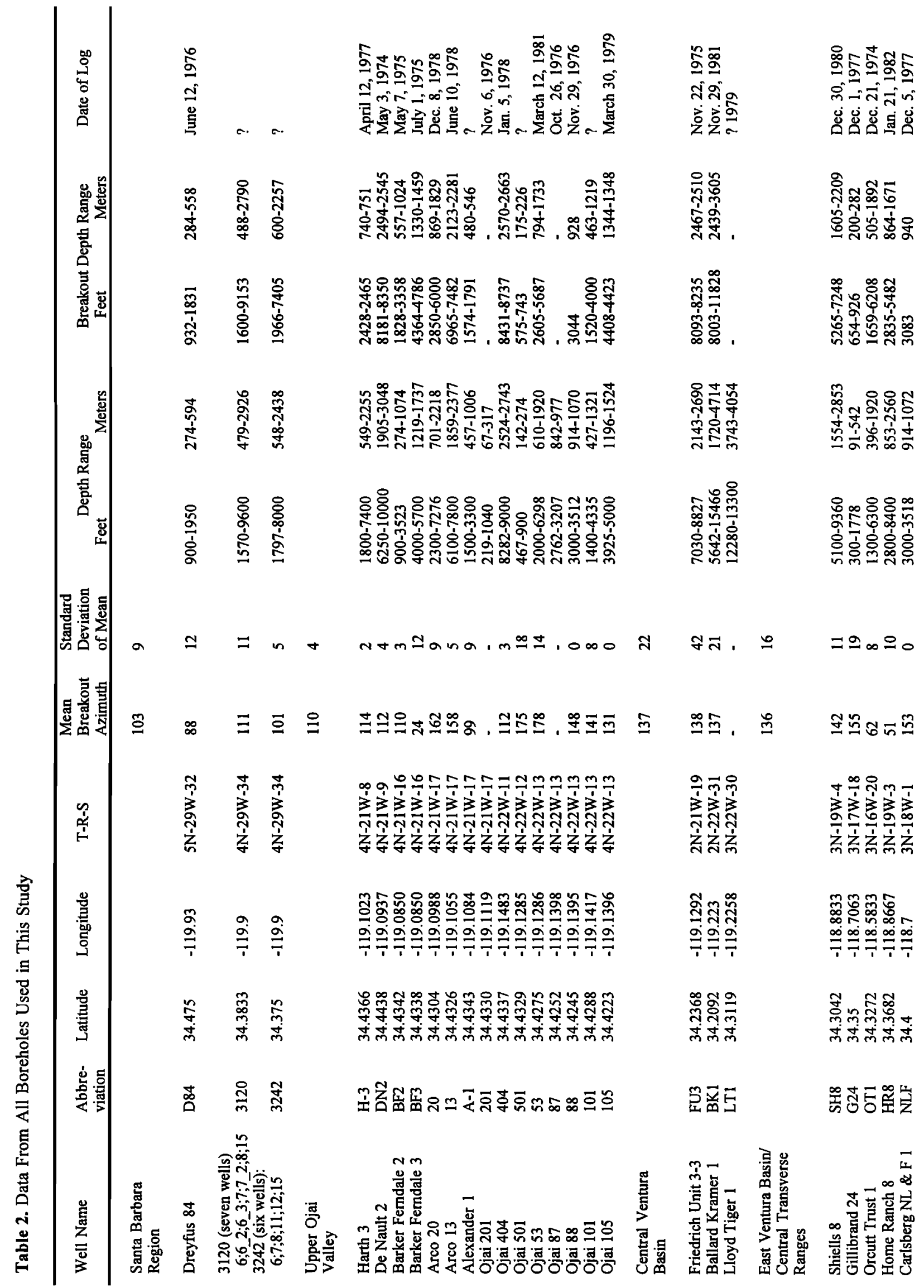




\begin{tabular}{|c|c|c|c|c|c|}
\hline 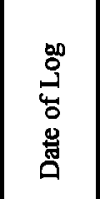 & 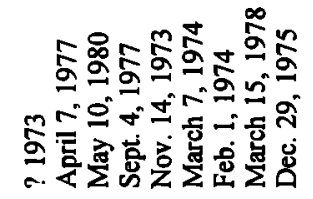 & & 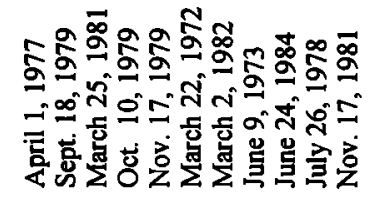 & & 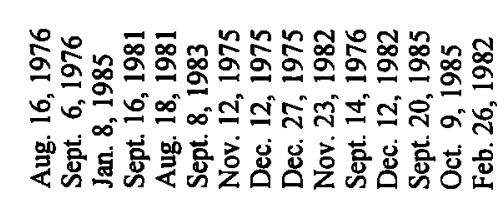 \\
\hline 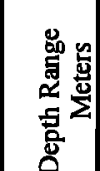 & 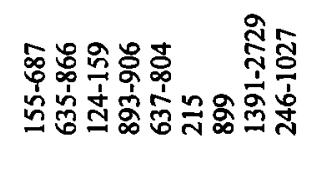 & & 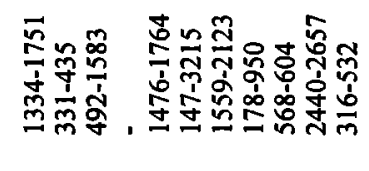 & & 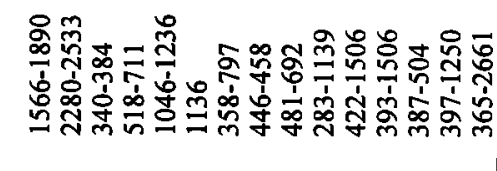 \\
\hline 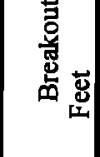 & 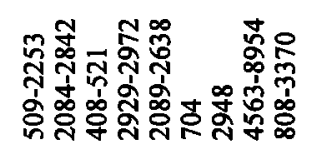 & & 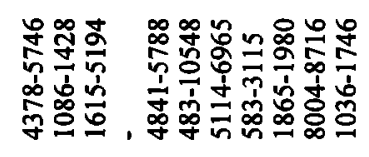 & & 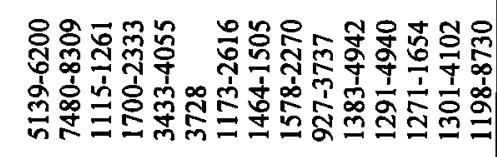 \\
\hline 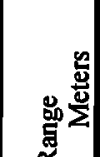 & 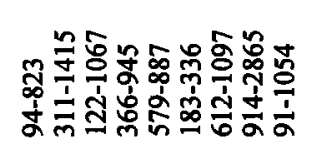 & & 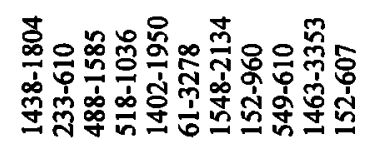 & & 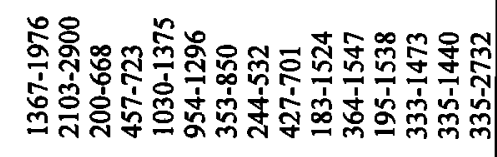 \\
\hline $\overrightarrow{\mathrm{E}}$ & 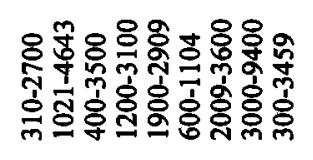 & & 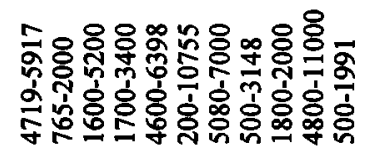 & & 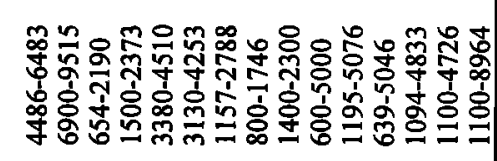 \\
\hline & $\exists a \pm m+00-=$ & \pm & 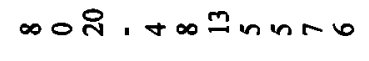 & $\ddot{\lambda}$ & nกー \\
\hline 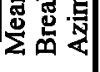 & 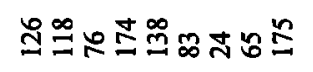 & 8 & 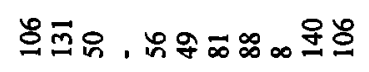 & $\bar{m}$ & 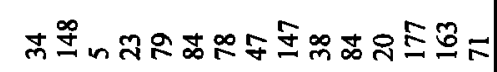 \\
\hline 悉 & 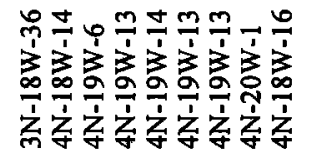 & & 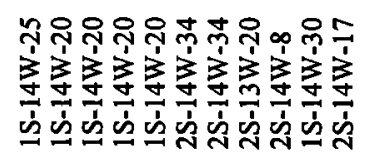 & & 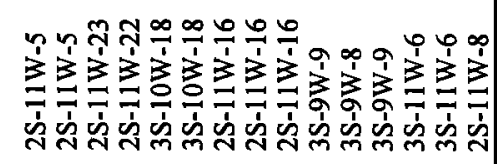 \\
\hline 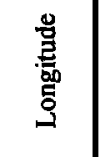 & 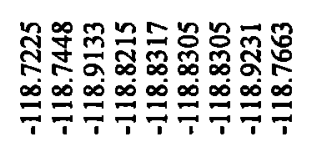 & & 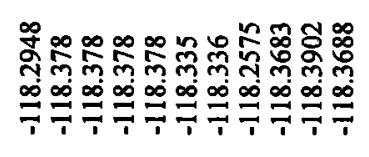 & & 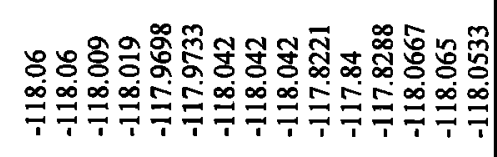 \\
\hline 苋 & 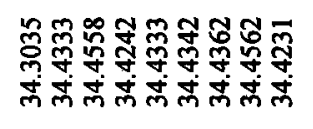 & & 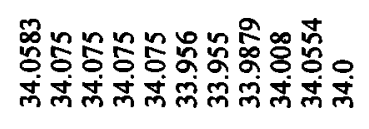 & & 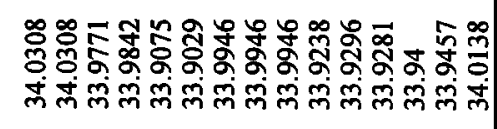 \\
\hline 递㚜 & 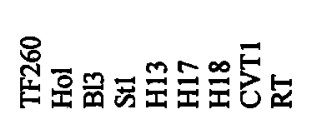 & & 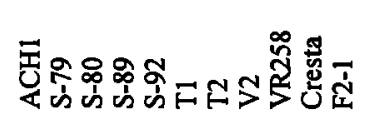 & & 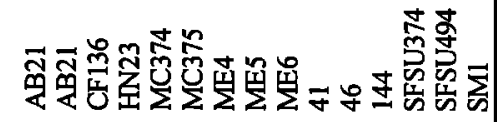 \\
\hline $\begin{array}{l}\frac{\mathscr{g}}{\mathrm{G}} \\
\overline{\mathrm{s}}\end{array}$ & 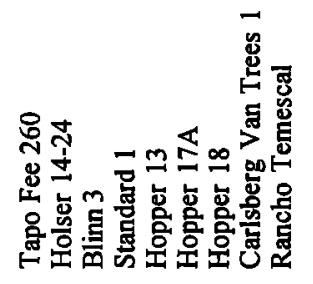 & 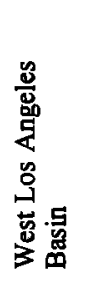 & 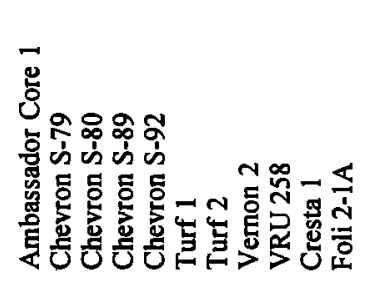 & 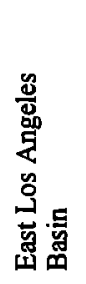 & 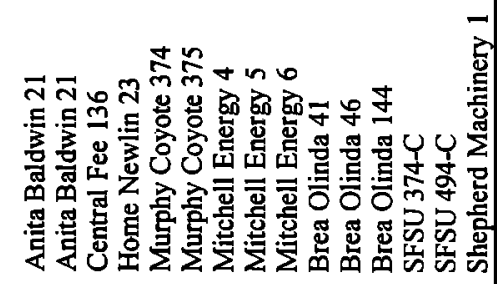 \\
\hline
\end{tabular}




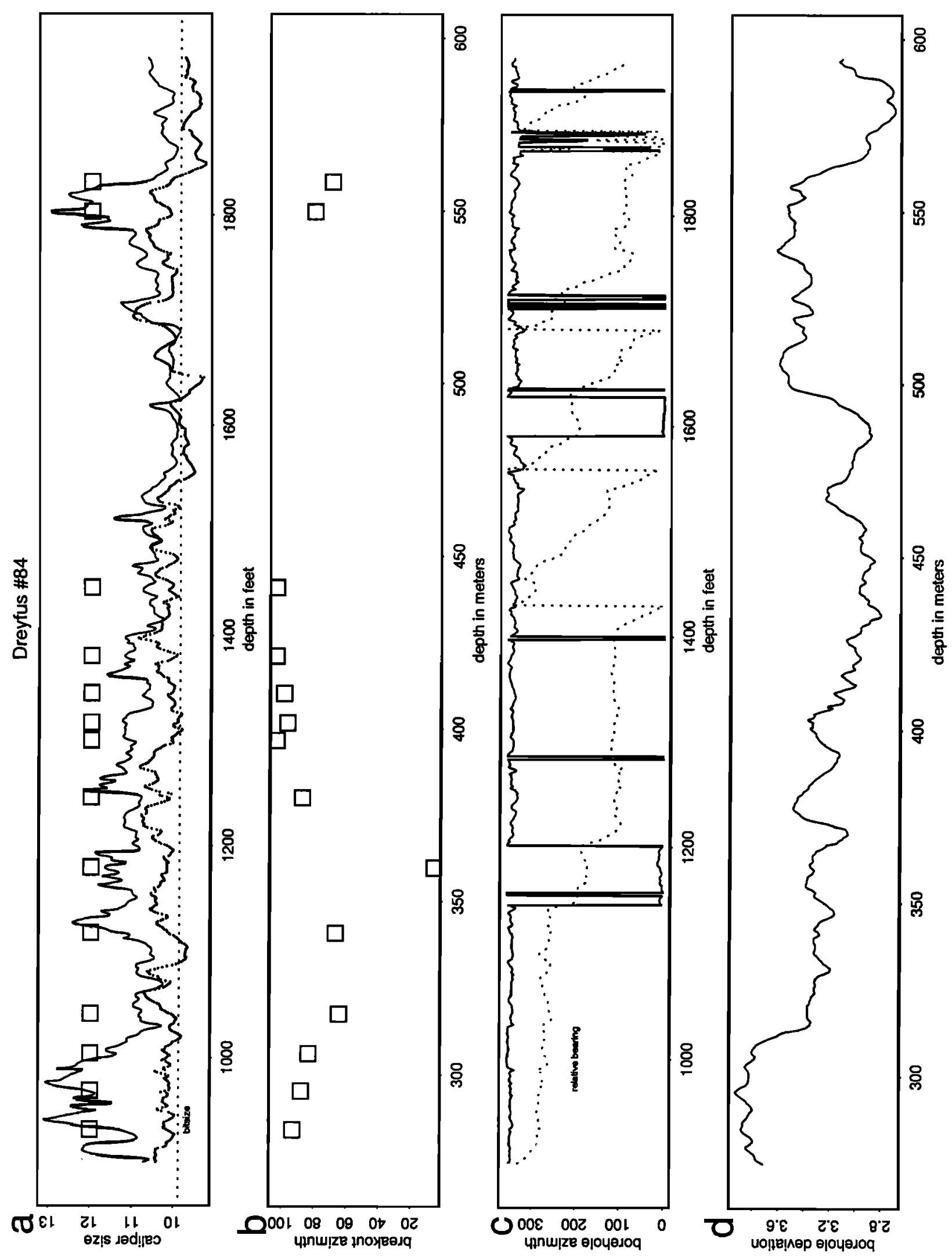




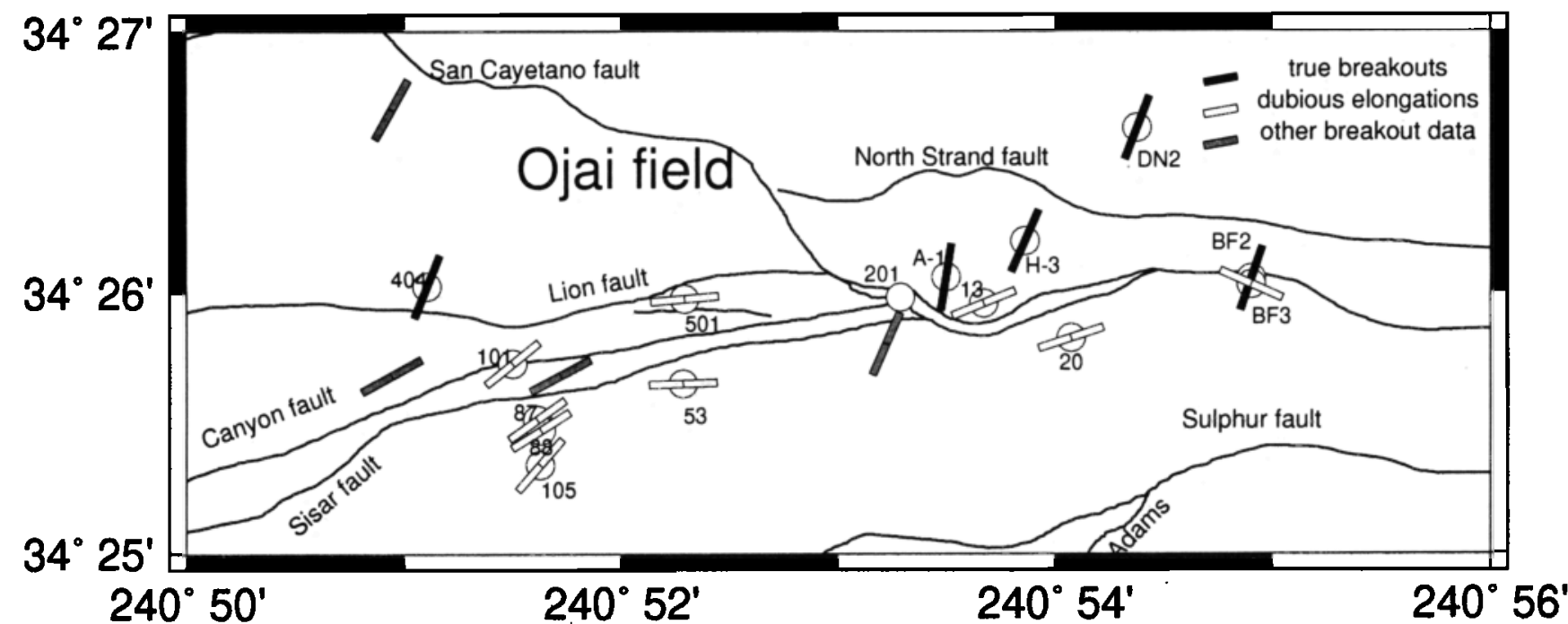

Figure 5. Map of the Upper Ojai Valley area, in the region T4N, R21W-R22W. Circles show the locations of the 15 drill holes analyzed here. Thick lines are the direction of maximum horizontal compressive stress indicated by borehole elongations: Solid lines indicate holes for which we consider the elongation data to be reliable (breakouts); open lines are those holes for which the elongation data are probably the result of key seats in the hole and do not reliably indicate the stress direction. The reliable data provide a very consistent direction of $S_{\mathrm{H}}$ of $\mathrm{N} 20^{\circ} \mathrm{E} \pm 4^{\circ}$. Grey thick lines show data from other studies of borehole breakouts [Zoback, 1992]. The fault lines are plotted after Rockwell [1988] and Huftile [1991].

ACH1 and T2, would imply $S_{\mathrm{H}}$ orientations of north to NNE, which are more in accord with other regional data discussed later. Although holes T1 and VR258 are also near vertical, their breakout observations come from shallower depths and thus may be less representative of the regional stress field (see Discussion section below).

For sections of borehole at higher deviation values, wells S92 and $\mathrm{T} 1$ showed radial breakout patterns, and V2 showed nearly radial breakout patterns. Wells S-80, F2-1, and S-79 showed nonradial breakout patterns. The presence of conflicting data points (e.g., V2 data points and S-80 data points for holes trending ESE and with deviations $>44^{\circ}$, Figure $3 \mathrm{e}$ ) indicates that there is not a single stress field operating over the entire volume represented by the borehole data. However, the relevant V2 data are from shallower depths than the relevant conflicting S-80 data, so perhaps in the determination of a regional stress field more weight might be given to the data from hole S-80.

If we eliminate the radial data from hole $S-92$, the overall data set is consistent with $\mathrm{E}-\mathrm{W}$ trending breakouts and a $\mathrm{N} 0^{\circ} \mathrm{E} \pm 14^{\circ}$ direction of $S_{\mathrm{H}}$.

A possible theoretical stress state corresponding to these data would be a thrust faulting stress regime with a N-S orientation of the maximum horizontal principal stress (Figure 2, top middle). The $\phi$ value cannot be well constrained, because of the limited variability in borehole deviations. The disagreement in breakout orientations between the S-80 data and the V2 data suggests that there may be a nodal point to the stress field, located at approximately SE trend, $45^{\circ}$ deviation, but the data are too scattered to constrain this well. A combination strike-slip and thrust faulting stress regime is another interpretation consistent with the available data (Figure 2, top right).

East Los Angeles Basin. In the East Los Angeles Basin, along and south of the Whittier fault (Figure 1), the 14 boreholes analyzed show a very different pattern of borehole breakouts than that seen in the data from the West Los Angeles Basin. The breakout azimuths are very variable, with an average direction of $\mathrm{N} 31^{\circ} \mathrm{E} \pm 23^{\circ}(1 \sigma)$ implying an $S_{\mathrm{H}}$ direction of $\mathrm{N} 59^{\circ} \mathrm{W} \pm 23^{\circ}$.

If we look only at the breakouts in near-vertical sections of the drill holes (deviation less than $11^{\circ}$, Figure 3f), we can divide the observations into several groups. Wells $46, \mathrm{MC} 374$, MC375, SFSU494, SFSU374, AB21, and 41 all have data at borehole deviations less than $11^{\circ}$. MC374 and MC375 show similar breakout orientations $\left(79^{\circ}\right.$ and $84^{\circ}$, respectively), suggesting that they are in a zone in which $S_{\mathrm{H}}$ trends $\mathrm{N} 11^{\circ} \mathrm{W}$ to $\mathrm{N} 6^{\circ} \mathrm{W}$. The sparse breakouts in the Brea Olinda 46 hole show a similar orientation, suggesting that $S_{\mathrm{H}}$ trends nearly N-S there. However, Brea Olinda 41 , which is near Brea Olinda 46 , has breakouts trending $\mathrm{NE}$, suggesting an $S_{\mathrm{H}}$ direction of

Figure 4 (opposite). Plot showing details of data for Dreyfus 84 borehole located in the Santa Barbara region. Similar data for different wells are available from the authors. (a) Caliper measurements as a function of depth, with bit size shown as dotted line and positions of identified breakouts shown with open squares. Caliper scale is in inches. Depth scale is in distance along the borehole and does not correspond to true vertical depth. (b) Breakout azimuth as a function of depth. Note that the technique of breakout identification from four-arm caliper data, used here, assumes that the breakouts are symmetric; thus only azimuths from $0^{\circ}$ to $180^{\circ}$ are shown. (c) Borehole azimuth (solid line) and bearing of pad 1 relative to high side of hole (dotted line). Zones where the relative bearing changes rapidly, e.g., between 1450 feet and 1800 feet $(442-550 \mathrm{~m})$, indicate that the tool is rotating. These are regions where the caliper measurements are equal to bit size, as often expected in zones lacking breakouts. (d) Borehole deviation from vertical as a function of depth. 
$\mathrm{N} 52^{\circ} \mathrm{W}$. And the two SFSU holes appear to be in a region with yet another direction of $S_{\mathrm{H}}$. Breakout directions of $\mathrm{N} 177^{\circ} \mathrm{E}$ and $\mathrm{N} 163^{\circ} \mathrm{E}$ in these two holes suggest that they are affected by $S_{\mathrm{H}}$ trending roughly north to NNE.

Some of the deeper breakouts from this region come from the AB21 drill hole. These show two populations of breakouts: from $5100-6200$ feet $(1555-1890 \mathrm{~m})$ depth, a very consistent breakout direction of $\mathrm{N} 34^{\circ} \mathrm{E} \pm 5^{\circ}$; and from $7500-8300$ feet (2286-2530 m) depth, scattered breakouts at a variety of orientations. We consider the first population to be the most reliable, suggesting that $S_{\mathrm{H}}$ is oriented $\mathrm{N} 56^{\circ} \mathrm{W}$ at this hole.

At higher borehole deviations, radial or nearly radial breakouts are observed in holes Mitchell Energy 5 (ME5), Home Newlin 23 (HN23), Central Fee 136 (CF136), and Brea Olinda 144 (Figure 3f). Some of the breakouts in holes Shepherd Machinery 1 (SM1) and Mitchell Energy 4 (ME4) are radial, but there are a significant number of nonradial breakouts also. The nonradial breakouts at higher hole deviations are generally consistent with a north to NNW direction of compression.

In this region, there is clearly considerable variability in the direction of compression. Northwest to NNW directions of $S_{\mathrm{H}}$ appear to be localized in the region nearest to the Whittier fault (Figure 1); $S_{\mathrm{H}}$ directions derived from holes more distant from the Whittier fault, such as the two SFSU holes or the Murphy Coyote holes, are north trending to NNE trending, more in accordance with other regional stress indicators, discussed below. This may be due to lateral variations in the stress directions, possibly controlled by active structures such as the Whittier fault. However, there is also a possible change in the stress field with depth. The breakouts seen in the two SFSU holes are dominantly from depths $<2500$ feet $(<762 \mathrm{~m})$. Deeper breakouts in both of these holes trend ENE, in agreement with the data from the MC374 and MC375 holes, which are from depths $>3000$ feet $(>914 \mathrm{~m})$. Thus the $S_{\mathrm{H}}$ direction at depth may be more consistent and may be oriented $\mathrm{N} 10^{\circ} \mathrm{W}$ to $\mathrm{N} 15^{\circ} \mathrm{W}$.

\section{Discussion: Overall Patterns of Stress in Southern California}

A variety of studies indicate that southern California, west of the San Andreas fault, is characterized by variable stress regimes including both thrust faulting and strike-slip faulting, with the direction of maximum horizontal compression oriented NE to NNW [e.g., Zoback and Zoback, 1980; Zoback, 1992; Hauksson, 1990; Jones, 1988]. Some large-scale structural control on variations in this overall stress field has been proposed; for example, a low-strength San Andreas fault may result in rotation of the principal compression direction into perpendicularity with the fault, so that the $S_{\mathrm{H}}$ direction very close to the fault may differ from that some distance away [e.g., Zoback et al., 1987]. This line of reasoning is consistent with many of the stress indicators from the central California section of the San Andreas fault [Mount and Suppe, 1992; Zoback et al., 1987] and was also used to explain the average $N 59^{\circ} \mathrm{E} \pm 17^{\circ} \mathrm{di}-$ rection of $S_{\mathrm{H}}$ seen in the Cajon Pass borehole [Shamir and Zoback, 1992]. This borehole is located $4 \mathrm{~km}$ from the San Andreas fault and $\sim 15 \mathrm{~km}$ east of the center right edge of Figure 1. The region of our study appears to be generally too far from the San Andreas fault to be demonstrating fault-normal compression related to it.

One of the notable results of stress studies in the Cajon Pass borehole was a thorough documentation of depth-dependent variations in the stress field over very short distances. At hole deviations everywhere $<6^{\circ}$, in the depth range $1750 \mathrm{~m}$ to 3450 $\mathrm{m}$, borehole televiewer logs showed that the breakout orientations had both continuous and discontinuous changes in orientation, as well as gaps. These features were attributed to stress perturbations along active faults [Shamir and Zoback, 1992]. Changes in breakout orientation of $10^{\circ}-25^{\circ}$ were common, but larger changes were observed, particularly at extremely fractured intervals [Shamir and Zoback, 1992]. Because a borehole televiewer was used to identify the breakouts, there is no possibility that other types of borehole elongations were mistaken for breakouts. It is also noteworthy that the stress state inferred from the Cajon Pass drill hole is not identified from inversion of focal mechanisms in the same region [Jones, 1988], suggesting that the stress state seen in this drill hole may not be regionally representative.

Shamir and Zoback [1992] suggested that the heterogeneity in the stress field at the Cajon Pass drill hole might characterize substantial distances along and across the San Andreas fault system. Such heterogeneity has not been recognized in regional stress field studies based on seismic data from southern California west of the San Andreas fault. These studies yield overall $S_{\mathrm{H}}$ directions ranging from $\mathrm{N} 1^{\circ} \mathrm{W}$ to $\mathrm{N} 32^{\circ} \mathrm{E}$, from inversions of focal mechanisms [Hauksson, 1990] and an $S_{\mathrm{H}}$ direction of $\mathrm{N}-\mathrm{S} \pm 15^{\circ}$ based on shear wave splitting [ $L i$ et al., $1994 ; L i, 1996]$. However, both of these techniques are more sensitive to deformation and/or crack orientations at depths > $5 \mathrm{~km}$, within the basement, and might plausibly yield results different from those seen in drill holes at shallower levels. It is possible that throughout most of southern California, the scale of stress variation in the upper $5 \mathrm{~km}$ is similar to that inferred for the region of the Cajon Pass drill hole but is not detectable by using earthquake-based methods.

Our data show substantial variation in the direction of stress in the shallow crust in southern California. This is consistent with previous studies; for example, Mount and Suppe [1992] report elongation directions ranging from $88^{\circ}$ to $159^{\circ}$ from wells in the region of our study, which would correspond to a range of $S_{\mathrm{H}}$ directions from $\mathrm{N} 2{ }^{\circ} \mathrm{W}$ to $\mathrm{N} 49^{\circ} \mathrm{E}$. We have studied a more dense network of holes than were examined by Mount and Suppe [1992], enabling us to better determine the amount of lateral variability in the stress field and to see possible causes.

\section{Conclusions}

We can infer some details of the regional pattern of the stress field from our analysis of 71 well logs from Santa Barbara to the Los Angeles Basin, using the orientations of maximum horizontal principal stresses determined for each borehole.

The boreholes were divided into six geographic areas (Santa Barbara area, Upper Ojai Valley, Central Ventura Basin, East Ventura Basin/Central Transverse Ranges, West Los Angeles Basin, and East Los Angeles Basin) due to the possibility of different states of stress corresponding to different fault systems. The analysis suggests a thrust faulting or strike-slip faulting stress regime in all six areas, with different orientations of the maximum horizontal principal stresses for each area (Table 1 and Figure 1). These directions of maximum horizontal

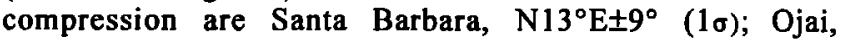
$\mathrm{N} 20^{\circ} \mathrm{E} \pm 4^{\circ}$; Central Ventura Basin, $\mathrm{N} 47^{\circ} \mathrm{E} \pm 22^{\circ}$; Eastern Ventura Basin, $N 46^{\circ} \mathrm{E} \pm 16^{\circ}$, excluding data in the extreme eastern zone, which suggest a local NW direction of compression; west Los Angeles Basin, $\mathrm{N}^{\circ} \mathrm{E} \pm 14^{\circ}$; east Los Angeles Basin, $\mathrm{N} 59^{\circ} \mathrm{W} \pm 23^{\circ}$ (the high scatter here suggesting that this is probably not a uniform stress regime).

Within some areas (such as the East Ventura Basin and East Los Angeles Basin study areas), considerable variations in horizontal stress directions are visible. The change to NW directions of compression in the easternmost Ventura Basin region is believed to reflect a structural change in the fault patterns of the shallow crust, analogous to that noted previously by Kerkela and Stock [1996] from drill holes in the San Fernando Valley region (data point labeled K-S on Figure 1). 
Similar NW directions of compression are found in wells near the Whittier Fault and may reflect a similar local perturbation in the stress regime there. Some shallow wells more distant from the Whittier fault also show this NW direction of $S_{\mathrm{H}}$, but deeper wells at the same distance from the fault show a north to NNW direction of $S_{\mathrm{H}}$

It is clear that on the whole, there appear to be systematic variations in the directions of maximum horizontal stress in the shallow crust in this region. This study supports heterogeneity in the regional stress field (similar to that shown for the Cajon Pass borehole by Shamir and Zoback [1992]) and reflects the complexity of faulting in this area. In this region, where shallow thrust faults appear to play a significant role in seismic activity, detailed mapping of in situ stresses is required if we are to understand the mechanics of these faults and their potential for seismic failure. The use of recently developed techniques to determine the full stress tensor in deviated boreholes (e.g., Zajac and Stock, 1997) would lead to more complete information. The need for acquisition and analysis of more data utilizing current technologies is obvious from our results.

Acknowledgments. Some data were graciously provided by J. Scott Hornafius and Laird Thompson of Mobil Exploration \& Producing U. S. This work was supported by the Southern California Earthquake Center via NSF grant EAR 89-20136. Contribution 5656 of the Caltech Seismological Laboratory. SCEC publication 320 . The early phases of this research were supported by the U.S. Geological Survey (USGS), Department of the Interior, under USGS award 1434-93-G-2297. The views and conclusions contained in this document are those of the authors and should not be interpreted as necessarily representing the official policies, either expressed or implied, of the U.S. Government. We thank Colleen Barton and an anonymous reviewer for very helpful reviews. Further details of the observations presented in this paper can be accessed on the internet at http://www.scecdc.scec.org/stress.

\section{References}

Baumgartner, J., J. Carvalho, and J. McLennan, Fracturing deviated boreholes: An experimental laboratory approach, in Rock at Great Depth, Proceedings ISRM-SPE International Symposium, pp. 929937, A. A. Balkema, Brookfield, Vt., 1989.

Daneshy, A. A., A study of inclined hydraulic fractures, Soc. Pet. Eng. $J ., 13,61-68,1973$.

Harris, R. A., and R. W. Simpson, Changes in static stress on southern California faults after the 1992 Landers earthquake, Nature, 360, 251-254, 1992.

Hauksson, E., Earthquakes, faulting, and stress in the Los Angeles Basin, J. Geophys. Res., 95, 15,365-15,394, 1990.

Huftile, G. J., Thin-skinned tectonics of the Upper Ojai Valley and Sulphur Mountain Area, Ventura Basin, California, $A A P G$ Bull., 75 , 1353-1373, 1991

Jaumé, S. C., and L. R. Sykes, Changes in state of stress on the southern San Andreas fault resulting from the California earthquake sequence of April to June 1992, Science, 258, 1325-1328, 1992.

Jones, L. M., Focal mechanisms and the state of stress on the San Andreas fault in southern California, J. Geophys. Res., 93, 88698891, 1988.

Kerkela, S., and J. Stock, Compression directions north of the San Fernando Valley determined from borehole breakouts, Geopinys. Res. Lett., 23, 3365-3368, 1996.
Li, Y., Shear wave splitting observations and implications on stress regimes in the Los Angeles Basin, California, J. Geophys. Res., 101, 13,947-13,961, 1996.

Li, Y., T. L. Teng, and T. L. Henyey, Shear-wave splittıng observations in the northern Los Angeles Basin, southern Californıa, Bull. Setsmol. Soc. Am., 84, 307-323, 1994.

Mastin, L., Effect of borehole deviation on breakout orientations, $J$. Geophys. Res., 93, 9187-9195, 1988.

Moos, D., and M. D. Zoback, Utilization of observations of well bore failure to constrain the orientation and magnitude of crustal stresses: Application to continental, Deep Sea Drilling Project, and Ocean Drilling Program boreholes, J. Geophys. Res., 95, 9305-9325, 1990.

Mount, V. S., and J. Suppe, Present-day stress orientations adjacent to active strike-slip faults: California and Sumatra, J. Geophys. Res., 97, 11,995-12,013, 1992.

Peska, P., and M. D. Zoback, Compressive and tensile failure of inclined well bores and determination of in situ stress and rock strength, $J$. Geophys. Res., 100, 12,791-12,811, 1995.

Plumb, R.A., and S. H. Hickman, Stress-induced borehole elongation: A comparison between the four-arm dipmeter and the borehole televiewer in the Auburn geothermal well, J. Geophys. Res., 90, 5513$5521,1985$.

Qian, W., and L. B. Pedersen, Inversion of borehole breakout orientation data, J. Geophys. Res., 96, 20,093-20,107, 1991

Richardson, R. M., Hydraulic fracture in arbitrarily oriented boreholes: An analytic approach, in Proceedings of a Workshop on Hydraulic Fracturing Stress Measurements, pp. 167-175, Natl. Acad. Press, Washington, D. C., 1981.

Rockwell, T., Neotectonics of the San Cayetano fault, Transverse Ranges, California, Geol. Soc. Am. Bull., 100, 500-513, 1988.

Shamir, G., and M. D. Zoback, Stress orientation profile to $3.5 \mathrm{~km}$ depth near the San Andreas fault at Cajon Pass, California, J. Geophys. Res., 97, 5059-5080, 1992.

Stein, R. S., G. C. P. King, and J. Lin, Stress triggering of the $1994 M=6.7$ Northridge, California, earthquake by its predecessors, Science, 265 , 1432-1435, 1994.

Vermik, L., and M. D. Zoback, Estimation of maximum horizontal principal stress magnitude from stress-induced well bore breakouts in the Cajon Pass scientific research borehole, J. Geophys. Res., 97, 5109$5119,1992$.

Zajac, B., and J. M. Stock, Using borehole breakouts to constrain the complete stress tensor: Results from the Sijan Deep Drilling Project and offshore Santa Maria Basin, California, J. Geophys. Res., in press, 1997.

Zajac, B., J. Stock, and J. Shemeta, Cook Inlet stress state from breakouts in deviated boreholes, Eos Trans. $A G U, 75$, (44), Fall Meet. Suppl., $592,1994$.

Zoback, M.D., et al., New evidence on the state of stress of the San Andreas fault system, Science, 238, 1105-1111, 1987.

Zoback, M. L., First- and second-order patterns of stress in the lithosphere: The World Stress Map Project, J. Geophys. Res., 97, 11,703$11,728,1992$.

Zoback, M.L., and M. D. Zoback, State of stress in the conterminous United States, J. Geophys. Res., 85, 6113-6156, 1980.

M. Wilde and J. M. Stock, Seismological Laboratory 252-21, Californıa Institute of Technology, 1200 E. California Blvd., Pasadena, CA 91125 (e-mail: wilde@gps.caltech.edu; jstock@gps.caltech.edu)

(Received March 15, 1996; revised October 1, 1996; accepted November 27, 1996.) 